\title{
THE EFFECT OF LINE DRAWING IN TEACHING ENGLISH VOCABULARY AT THE SEVENTH GRADE STUDENTS OF SMPN 19 MATARAM IN ACADEMIC YEAR 2016/2017
}

\author{
(1) Yulia Isnaini (2) Farniati Lisani \\ (1) Lecturer of English Department Muhammadiyah University of Mataram \\ (2) Student of English Department Muhammadiyah University of Mataram
}

\begin{abstract}
Abstrack
Line drawing is the draw which can made in the board directly in the classroom or it can be prepared in certain papers before entering the classrom. The aim of this research was to investigate the use of line drawing has effect or not in teaching English vocabulary at the seventh grade students of junior high school. The research was conducted the first semester at the seventh grade students of SMP Negeri 19 Mataram. The population in this research was the seventh grade students of SMP Negeri 19 Mataram, in which the total number of class were five classes and in this research just conducted in two classes. The sampling technique was cluster sampling. The total numbers of the students as sample were 62 students from two classes and each class consist of 31 students. During period of time, the experimental group was treated by using line drawing and the control group was treated without using line drawing. The result of the research reveals that the mean score of the experimental group is 24.6 and the control group is 12.9. In the otherhand, the standar deviation of the experimental group is $2.8>1.5$ under the identification of $\mathrm{t}$ - test formula. It is found that the value of it is $5.62>0.05 \%$ and $0.01 \%$ at the degree of freedom infinitive which is 1.67 and 2.39. From this point, it can be concluded that the alternative hyphothesis is accepted or the line drawing has effect in teaching English vocabulary at the seventh grade students of SMPN 19 Mataram.
\end{abstract}

Key Word: Line Drawing, Vocabulary

\section{A. Introduction}

The developing of knowledge in the education, not only demand students to know English from Elementary but also University level. There are also other skills of language which advocate the mastery of those four skills, they are vocabulary, speaking, reading and writing. The most important skills to master is vocabulary. Mastering vocabulary is the most important part of studying English. Without sufficient vocabulary, we can't understand the meaning of words, text passage and some literatures. As we know that student still have problem with vocabulary, they will confuse with the meaning of the word. They can't express their feeling because of the lack of vocabulary.

In learning English especially in learning vocabulary, learning language needs repetiting, memorizing and doing practice of vocabularies. Based on the observation at SMPN 19 Mataram, the researcher found that the students were afraid to talk because of less vocabularies, wrong spelling, wrong prononciations, etc. It also needs an interesting way used by their teacher. The teacher needs some models in teaching vocabulary. One of models 
for stimulating students' interest is by using instructional media. Instructional media is a way to attract students' attention and to deliver information. There are various kinds of visual media which can be effectively used by English teacher in teaching vocabulary in the classroom.

Based on the statements of the problems above, the objectives of the study is; To investigate the use of line drawing has effect or not in teaching English vocabulary at the seventh grade of SMPN 19 Mataram in academic year 2016/2017.

\section{B. Review of related literature}

\section{Definition of Media}

Media are mediator for delivering information between source and receiver. Gerlach and Ely (1971) in Arsyad (2014: 3) media is human, material or events that establishes the conditions that enable the pupils to acquire knowledge, skills, or attitudes. The next, Arsyad (2014: 3) states that the media is a tool that conveys or delivers messages of learning. Hornby in oxford dictionary (2005: 268) state that media is way of communicating information etc, to people, or something that is used for particular person.

\section{Kinds of Media}

\section{a. Visual Media}

Visual media is a media provided to deliver information or messages from resource to the students. The message in extended by communicative symbols. Visual media is also used to attract and increase the students' attention, clarify the ideas and strengthen students' memorizing in comprehending.

According to (Hasratul: 2010) there are many kinds of visual media such as: (1) chart, (2) real object, (3) realia (4) posters, (5) cartons, (6) flashcard and (7) line drawing. In this part, the researcher only states few. Those are chart, real objects, realia, poster and cartoon. And about line drawing will be discussed in next sessions.

1) Chart

Attempt in increasing student interest by using media as chart can be shown as a specific. They are vocabulary, grammar, speaking, etc. vocabulary introduce common words. It used for showing words like health, food and others.

2) Real Object

The teachers can make a collection of common object, such as; real object used in teaching language in the classroom. Real object can be cans, flags, tickets, bottles, toys pens, books, chairs, table, window, and etc. Students will understand about material that they are studying where they are shown by real object. It can facilitate the teacher presentation and practice of vocabulary.

3) Realia

Realia is the visual interaction and most closely associated with direct purposeful learning experience. This media makes the students understand about what they are studying easily. The realia may be made from plastic. It is consist of toy car, doll, box, cup, ship ticket, plastic fruit and etc. Which can be demonstrated based on the material in teaching learning process and 
4) Poster

it can attract students to interesting in learning too.

Poster is kinds of picture media. It can be found in market and shop. When teacher will uses this media in teaching learning process. The teacher must prepare his/her self before because this media is not easy to prepare. The teacher can buy it in shop and can take it from calendar. This media has function to make student easier to understand about material.

5) Cartoon

Cartoon is an interesting medium. Cartoon is suitable used in teaching language especially in teaching young learners, because it can grow students' attention and their understanding in teaching learning process.

6) Flashcard

Flashcard is big size usually is using paper that rather thick and it size A4. Flashcard more than used to all of the class. The using of flashcard in class activity in English language can help the teacher for:

a. Introducing and concept stable singular and plural

b. Introducing and number stable introducing and concept stable are a few and a lot of

c. Attractive the students attention with the picture that attractive that interesting

\section{b. Audio Media}

d. Giving the variation in teaching learning process

Audio media are different with visual media. This media only focused on listening. There are many kinds of audio media. Such as: radio, TV, tape recorder, DVD, VCD. All of them we can find in language laboratory. This media can attract students' attention in learning language. Millar, in (Djamarah, (1994: 94) says that more than one the characteristic of audiovisual tools that similar, to make easier to study.

\section{c. Project Media}

These media are most advantage than others media in teaching learning process. This media can be heard and seen by students directly. This media consist of slide, film strip, microfilm, television, video, game, and etc. Dwyer, (Djamarah, (1994: 100) say that studying to be perfect that only reach if used the audiovisual tools that closing with reality.

\section{The Function of Media}

According to Nana Sudjana (1991) in (Fathurrahman and Sutikno, 2014: 66) there are six functions of media:

a. As tools to achieve an effective teaching and learning situation.

b. The use of a teaching medium is an integral part of the teaching situation. This means that the teaching medium of instruction is one element that must be developed by teacher.

c. Integral to the purpose and content of learning

d. The use of media in teaching is not merely as an entertainment tool used as complements of the learning process in order to attract students attention. 
e. The use of media in teaching is preferred to accelerate the learning process and help students in understanding the teacher's explanation.

f. The use of media in teaching is preferred to enhance the quality of teaching and learning.

\section{Line Drawing of Line Drawing}

Line drawing is kind of visual media. It consists of two words, those are lines and drawings. According to Echols and Shadily (2000:359) line is garis and drawing is gambar. So, line drawing is gambar garis. Hornby (2005: 250) state that line drawing is drawing done with pen, pencil, etc'. According to Arsyad (2014: 111) a line drawing is a simple image like a sketch. A line drawing, though very simple, it can show the impact of action or attitude that is quite good. Line drawing can convey a story or important messages. Line drawing can be done directly on the board in classroom or prepared on a sheet of cardboard outside of classroom with a suitable paper.

\section{Kinds of Line Drawing}

Hornby (2003: 250) state that line drawing is a drawing done with pen, chalk, board marker and pencil. Based on the form and characteristic, there are some kinds of line drawing such as stick figure, graph, sketch, and pin card.

1. Stick Figure

Stick figure is kinds of media. It is made by teacher on blackboard or whiteboard related to material and theme that will be taught in classroom. The teacher can make stick figure with determining the character of picture that drawn, example; if the teacher make or draw smile face and angry face, they must be differenced with their characters. Arsyad (2014: 114) says stick figure is simple drawing that is like sketch. For example; drawing about someone running and someone sitting have different character.

2. Graph

Graph is simple media, which uses blanks, line and picture (Arsyad, 2007: 117). Graph describes quantitative data; it compares several objects shortly and clearly. There are many kinds of graph such as; stick graph, line graph and circle graph.

3. Sketch

Sketch is a simple picture. Teachers may explain the object after the show, for example, describes a butterfly, teachers can describe the process of drafting the butterflies from larvae, and others. And other explanations, sketches can be used.

4. Pin Card

Pin card is media which is made by teacher. The teacher draws something only use line. For example, draw part of body only use line, draw part of house only use line.

\section{Definition of Vocabulary}

According to Abdul (2013: 7) Vocabulary is essential in learning a foreign language, in this case English. It is the basic of the four skills of English which learnt in order to communicate well in the language. In order words, we cannot communicate in English without knowing words of the language.

\section{The Importance of Vocabulary}

The importance of vocabulary will be elaborated in the following discussions: 
First, Vocabulary or words have a definite power. According to Mikulski \& Templeton (2004) in (Hilwatun 2015):

"Words literally have changed and will continue to change the course of world history. Perhaps the greatest tools we can give students for succeeding, not only in their education but more generally in life, is a large, rich vocabulary and the skills for using those words. Our ability to function in today's complex social and economic worlds inn mightily by our language skills and word knowledge."

Second, it determines learners aptitude since the entire of fluency skill relates on its mastery for instance it is needed to construct the meaninngful sentences. The learners use sentences either to express their experience while study or to definitely expand their knowledge. As baterman (n.d) in (Hilwatun: 2015) states that many people who have studied foreign language: recalling lists of vocabulary words, studying grammar rules, and then plugging the words into the grammatical patterns, with little regard for the meaning of the sentences they were producing. The learners are making progress when they are able to produce meaningful sentences. And vice versa if the learners cannot produce anything even for a few once, then it can be a crucial problem for their progress.

The last one, Vocabulary breaks the students limitation in mastering knowledge of English learning. It is central paart of language ability and provides lots of the starting point for students to speak, listen, read, and write. No effective mastery in vocabulary means difficult to take part in class. According to Nam, (2010) vocabulary is used as the bridge between students and content-are classes in that these students often find that lack of its knowledge is an obstacle to learning. It means tha lack of vocabulary will prevent students development in the study.

\section{Teaching Vocabulary}

Teaching new vocabulary is one effort in mastering and comprehending the next and producing speech fluency. The teachers have many manners in teaching vocabulary. They can choose the vocabulary frequently. The teacher should teach on the basic level and how frequently they are used by native speakers. The words are commonly used by native speakers are very important. If they are studied it firstly, such as the words in health, drink, eat, kill, buy, etc. The teachers will provide new vocabularies that help students in stating their mind and how they are processing or recognizing vocabularies that they are heard and read in the context or listening and reading.

The English language is cumpolsory subject for the Junior High School, Senior High School and University levels. Nation (2005: 342) states that there are some opinions about the principles that can be used in teaching vocabulary.

1. Keep the teaching simply and clearly, don't give complicated explanations.

2. Relate the present teaching to the past knowledge by showing an analogies pattern.

3. Use both of oral and written to presentation, write it on the blackboard as well as the explanation.

4. Give the most attention to the words which are already known.

5. Tell the students if it high frequency words that must be given the much attention.

6. Quickly give the meaning by: 
a. Showing the object or picture

b. Giving the quick demonstration

c. Drawing a simple picture

d. Breaking the words into the parts and giving the meaning into the parts and the whole words (the parts strategy)

e. Giving several sentences with the words in the context to show the meaning.

f. Underlying meaning of the words and the other references

7. Draw the attention to the form of the word by:

a. Showing how to spell the words that is like the spelling of known words

b. Giving the stress pattern of the words and how is is pronounced

c. Showing the prefix, stem and suffix that make up the word

d. Asking the students to repeat the pronunciation of the world

e. Writing the words on the board

f. Pointing out the way to spell the word

8. Draw attention to the use of the words by:

a. Quickly showing the grammatical pattern the words into countable/uncountable, transitive/intransitive, etc.

b. Giving a few similar collocates

c. Mentioning restrictions on the use of the word (formal, colloquial, impolite only used in the united state and it used by children, technical and frequency).

\section{Teaching Vocabulary by Using Line Drawing}

According to Arsyad (2014: 111) although it did not have the educational background art or painting, we can make a simple image like a sketch. Draw a line, though very simple, it can show the impact of action or attitude that is quite good. By drawing a line we can tell a story or important messages. In addition a line drawing can be done directly on the board in the classroom it can also be prepared in advance on a sheet of cardboard or paper accordingly. In making line drawings, the main feature of objects, actions or situations that would like to be described are must remain. A cheerful face can be distinguished from the frowning face with curved lines on the face (example, mouth and eyebrows). Examples of line drawings can be seen in the following drawing:
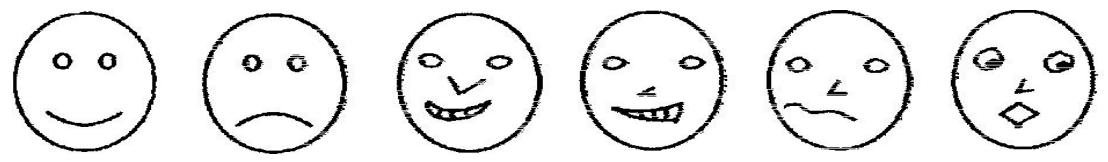

And other example of line drawing can be seen in the following drawing about someone is running and catch a dog (Arsyad, $2014: 112$ )
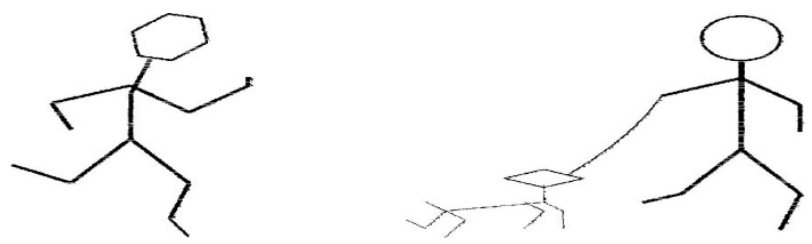
According to Arsyad (2014: 113) the introduction of early vocabulary as above is a supporter for the next lesson, for example, subject of the adjective "size" followed by other forms of comparison. So something line drawings can be created in a large size, long, tall, and others (Big houses, small houses, taller, shorter, and etc).

\section{Research Design}

\section{Research Design}

This research applied is experimental research that used quasi experimental design. This method as the most appropriate method in measuring the effect of line drawing in teaching English vocabulary.

\section{Population of the Study}

\section{a. Population}

The population of the research was the seventh grade students of SMPN 19 Mataram. There are 155 students which is divided into five classes, (class Aclass E).

\section{b. Sample}

The writer took two classes as the sample they were experimental class in class $\mathrm{C}$ and control class in class D. So, the total numbers of the students as sample were 62 students from two classes and each class consist of 31 students. The technique is cluster sampling.

\section{Research Instrument}

The writer used test as the instrument. The test that used was multiple choice test about vocabulary knowledge. The test consists of 20 items which gave 100 as maximum score. Each item was score 5 for correct answer and 0 for incorrect answer (Hasratul: 25). So in this case the maximum score was 100 and the minimum score is 0 .

\section{Data Collection Procedures}

In gathering the data, the researcher gave pre-test, treatment, and post-test to the students which consist of eight meetings.

1. The Pre-test

The writer gave the test before teaching vocabulary using line drawing. The writer wanted to know the basic knowledge and ability of students in mastering English vocabulary.

2. Treatment

The researcher gave the treatment to the students after pre-test. In this treatment, the researcher gave treatment eight times or eight meetings to the students by using Line Drawing especially vocabulary. The experimental group got the treatment by using Line Drawing, and the control group got the treatment by using other technique. After eight meetings, the researcher gave the post-test.

\section{Post-activity}

In this stage, researcher concluded and reinforced the material, did the reflection and then assigned students. While the control class was given the pre-test and post-test using other technique. 


\section{Research Findings and Discussion}

\section{Findings}

a) The Computation of Mean Score

The researcher used the following formula to look for the mean score of pretest and post-test:

a) $\mathrm{Mx}=\frac{\sum x}{N}$

b) $\mathrm{My}=\frac{\Sigma \mathrm{y}}{\mathrm{N}}$

Based on the data of pre-test and post-test, here was the computation of mean score:

1. Experimental Group

$$
\begin{aligned}
\mathrm{Mx} & =\frac{\sum x}{N} \\
& =\frac{765}{31} \\
& =24.6
\end{aligned}
$$

2. Control Group

$$
\begin{aligned}
\text { My } & =\frac{\sum y}{N} \\
& =\frac{400}{31} \\
& =12.9
\end{aligned}
$$

b) The Computation of Deviation Score

Based on the table above, the researcher looked for standard deviation score of two groups calculated by using the formula:

1. Standard Experimental Group

$$
\sum x=\sum_{21.683} y^{2}-\frac{(X)^{2}}{N x}
$$

$=21.683-\underline{585.225}$ 31

$=21.683-18.878$

$=2805$
2. Standard Control Group

$$
\begin{aligned}
\sum y & =\sum y^{2}-\frac{(\mathrm{Y})^{2}}{\mathrm{Ny}} \\
& =6.690-\underline{400^{2}} \\
& \quad 31 \\
& =6.690-160.000 \\
& \quad 31 \\
= & 6.690-5.161 \\
= & 1529
\end{aligned}
$$

c) The Computation of the t-test

After getting the students' mean score and the standard deviation score, the researcher continued to analyze the data by using the formula as follow:

$t=\frac{M x-M y}{\sqrt{\left[\frac{\left(\sum x 2+\sum y 2\right)}{N x+N y-2}\right]\left[\frac{1}{N x}+\frac{1}{N y}\right]}}$

$$
\begin{gathered}
t=\frac{M x-M y}{\sqrt{\left[\frac{\left(\sum x^{2}+\sum y^{2}\right)}{N x+N y-2}\right]\left[\frac{1+1}{N x+N y}\right]}} \\
=\frac{24.6-12.9}{\sqrt{\left[\frac{(2805+1529)}{31+31-2}\right]\left[\frac{1+1}{31+31}\right]}} \\
=\frac{11.7}{\sqrt{\left[\frac{4334}{60}\right]\left[\frac{2}{31}\right]}}
\end{gathered}
$$




$$
=\frac{11.7}{\sqrt{[72.2][0.06]}}
$$

$=\frac{11.7}{\sqrt{4.332}}$

$$
=\frac{11.7}{2.08}
$$

$=5,62$

The computation of t-value of the two groups equals 5.62 this figure is consulted to value of t-test on the table of critical t-value. However, before it is consulted the writer needs to determine the level of significance and to degree of freedom used in this study. Commonly in education research the level of significance used are 0,05 and 0,01 , while the degree of freedom is 60 . The level significance is $0,05 \%$ and $0,01 \%$ with degree of fredoom $62-2=60$. It can be seen that if we check up the $\mathrm{t}$-table, the writer found out the t-table for confidence $0,5 \%$ and $0,1 \%$ was 1,67 and at confidence level 0,01 or $99 \%$ was 2,39 . If we compared the test to the table we will find that:

T-test 5.62 $>$ t-table $=1,6795 \%$

T-test 5.62 $>$ t-table $=2,3999 \%$

\section{Discussion}

The researcher did the research in two classes. It applied in both of class $\mathrm{C}$ (experimental class) and class D (control class). Before the researcher gave the treatment, she gave pre-test to both classes. The test consisted of 20 numbers the tests were about vocabulary and spelling. In doing the test, the students got many difficulties; they were not familiar with some words about (parts of body), such as; moustache, leg, beard, etc. It was used to know the students' ability in vocabulary, example; 1. (parts of body), the words: eye, mouth, etc, 2. (classroom), the words: book, pencil, pen, chair, table, etc, 3. (bedroom), the words: bed, matress, mirror, etc and 4. (kitchen), the words: knife, pot, blender, etc. The test consisted of 20 numbers. Some of them got difficulties in answering the questions about spelling and vocabulary, such as in spelling word "towel" (question number 18 in post-test), the student (MA) answer was C (tie-ouc-dblyu-i-el) but the correct answer is B (ti-oudabelyu-i-el), the word "kettle" (question number 14 in post-test) the student (ASH) answer was C (kei-ie-ti-ti-el-ie) but correct answer is A (kei-i-ti-ti-el-i) and the vocabulary "tooth" (question number 2 in pre-test) the student (RB) answer was $\mathrm{C}$ (bottlo) but the correct answer is D (tooth) and After gave pre-test to the students, the researcher gave treatment to the students. The objective of this research was to investigate the use of line drawing has effect or not in teaching English vocabulary. The treatment that was given to the experimental class used line drawing. Meanwhile, the control class applied the technique that was used by their English teacher. Both of the groups were given different treatment.

In the last meeting, the students were given post-test. Kinds of the test were the different the pre-test. After giving the treatment, the result of students' was improved. The highest score was 95. It showed that line drawing is effect of line drawing in teaching vocabulary. 
The result of this research was successful. This statement was formulated by looking for the result of the data analysis. The $t$-test of this research was higher than the $t$ table. It means that the technique that was used in this research line drawing was effect of line drawing in teaching vocabulary.

It is clear that the Null Hypothesis (Ho) which stated "There is not effect of line drawing in teaching English vocabulary," is clearly rejected. Meanwhile, Alternative Hypothesis (Ha) which stated "There is effect of line drawing in teaching English vocabulary," is definitely accepted.

\section{E. Conclusion}

Based on the finding and discussion previously, it can be concluded that the use of line drawing media has significant effect in teaching vocabulary at the seventh grade students of SMPN 19 Mataram. From computation of correlation of the mean score of the two groups resulted the figure 5.62. This figure is the consulted to value of $t-$ test on the table of critical t-value and the level significance is $0.05 \%$ and $0.01 \%$ with degree of freedom $62-2=60$. So, by using line drawing in learning vocabulary can be improved students' vocabulary skill. Based on the result of the data analysis that t-test $5.62>$ t-table $=1,6795 \%$, t-test 5.62> t-table $=2,3999 \%$

It is clear that the Alternative Hypothesis (Ha) which stated "There is effect of line drawing in teaching English vocabulary," is definitely accepted.

\section{Bibliography}

Arikunto, Suharsimi, 2014. Prosedur Penelitian Suatu Pendekatan Praktik. Jakarta: Rineka Cipta

Ahmad, Ramli, 2010. A Thesis: The Effectiveness of Using Pictures to Develop Students ` Vocabulary: A Case Study at the Second Year of Smpn 3 Praya Tengah in Academic Year 2010/2011. Mataram. Unpublished

Arsyad, A. 2014. Media Pembelajaran. Jakarta : PT Raja Grafindo Persada

Baterman, B, 2016. Content-Based Language Learning and the Teaching of Vocabulary. Accessed from; http:www.2.vobs.at/ludescher/pdf\%20files/how/20to\%20teach\%20vocabulary.pdf on 2 nd 2016.

Diamond, Linda \& Gutlohn Linda, 2006. Teaching Vocabulary Retrieved from Internet

Djamarah, Syaiful Bahri, 1994. Prestasi Belajar dan Kompetensi Guru. Surabaya : PT. Usaha Nasional

Echols, John M, Hasan Shadily, 2000. An Indonesian-English Dictionary. Jakarta : PT. Ormedia.

Fathurrohman, P \& Sutikno, M.S. 2014. Strategi Belajar Mengajar : Bandung: PT Refika Aditama

Hasratul, A. 2010. A Thesis: The Effect of Line Drawing in the Teaching of English Vocabulary: A case Study at the Second Semester of Fifth Grade Students of SDN 5 Sakra in academic year 2010/2011. Mataram Unpublished.

Henriksen, B. 1996. Semantisation, Retention, and Accessibility: Key Concepts in Vocabulary Learning.

Hubbard, P. and AL 1983. A Training Course for TEFL. Oxford: OUP 
Hornby, as, 1983. Oxford Learner's Pocket Dictionary. New Edition. New York: Oxford University Press

Lanisia Helena Fortes Ferreira, 2007. How to Teach Vovabulary Effectively. Pdf

Lestarina, Rika, 2010. A Thesis: The Effectivenes of Using Pictures in Teaching Vocabulary $\therefore$ A Case Study at Secound Grade Students of MTs Al-Ikhlas Setungkep in Academic Year 2010/201. IKIP. Unpublished

Milkulski, J, J, and Shane, T, 2004. Teaching and Developing Vocabulary: Key to Long-Term Reading success. pdf by Houghton Mifflin Company. Retrieved on June 26th 2016

Nation, L.S.P, 2001. Learning Vocabulary in Another Language. Cambridge: Cambridge Universitas Press.

Nation, P. 2005. The Asian EFL Journal. Volume 7 issue 3 Victoria University of Wellington: New Zealand

Natiger, J. 1988. Some Currects Trends in Vocabulary Teaching in Mauan,

Nam, J, 2010. Linking Research and Practice: Effective Strategies for Teaching Vocabulary in the ESL Classroom, iteslj.org.

Sapatri, 2010. A Thesis: The Effectiveness of Using Scenary Pictures As a Teaching Media Increasing Students Achievement in Descriptive Text: An experimental study at the Second Year Students of Smpn 9 Mataram.IKIP. Unpublished.

Siriwan, M, 2007. A Thesis: English Vocabulary Learning Stategies. A Degree Thesis of Doctor of Philosophy in English Language Studies. University of Technology Suranaree.

Sugiyono, 2014. Metode Penelitian Kuantitatif, Kualitatif dan $R \& D$, Bandung: Alfabeta Thonbury, s, 2002. How to Teach Vocabulary: UK. Bluestone Press

Wahyuni, S. 2008. A Thesis: The Use of Relia in Teaching Vocabulary. A Case Study at the Second Year Students of MTs. Hidayatul Athfal Rebile in Academic Year 2008/2009. IKIP. Unpublished. 